\title{
5 The impact of economic globalisation on firm performance and the labour market: evidence from Japan
}

\author{
Keiko Ito
}

\section{Introduction}

The impact of globalisation on the economy and people's lives is attracting growing attention. In Japan, too, the economic impact of globalisation has been receiving significant interest, partly because there appears to be a link between the increase in trade and the overseas expansion of Japanese firms on the one hand and the prolonged sluggishness of the domestic economy on the other. In contrast to stagnant GDP growth, imports and exports and outward foreign direct investment (FDI) have increased, and as shown in Figure 5.1, the ratio of imports and exports and FDI to GDP has been rising sharply since the mid1990s in Japan. Against this background, there is a burgeoning literature on the impact of globalisation - in particular, international trade and FDI- on productivity and the labour market. While the empirical results differ across studies to some extent, a broad picture regarding the major issues, especially in developed countries including Japan, has emerged. This can be summarised as follows.

First, in developed countries including Japan, macro-level structural changes have been widely observed. The share of workers in the manufacturing sector has declined dramatically, although the value-added share of manufacturing has remained relatively stable. While there are a number of reasons for this structural change, globalisation is regarded as one factor that is at least partly responsible. Second, underlying such macro-level structural changes, various micro-level effects of globalisation have been observed. One stylised fact is that firms engaged in international trade and direct investment tend to be more productive than non-internationalised firms (see, for example, Bernard and Jensen, 1999; Mayer and Ottaviano, 2008; and Wakasugi et al., 2011). The former outperforms the latter not only in terms of productivity but also in terms of various other performance indicators such as research and development (R\&D) expenditure, patents, firm size, wage rates, and so on.

These changes are not necessarily bad for economic growth. The decline in manufacturing employment may accelerate economic growth if workers move towards fast-growing new industries. Moreover, if better-performing internationalised firms grow more and increase their shares in the economy, the efficiency of the economy overall is expected to be improved. The pro-competitive 
25

4

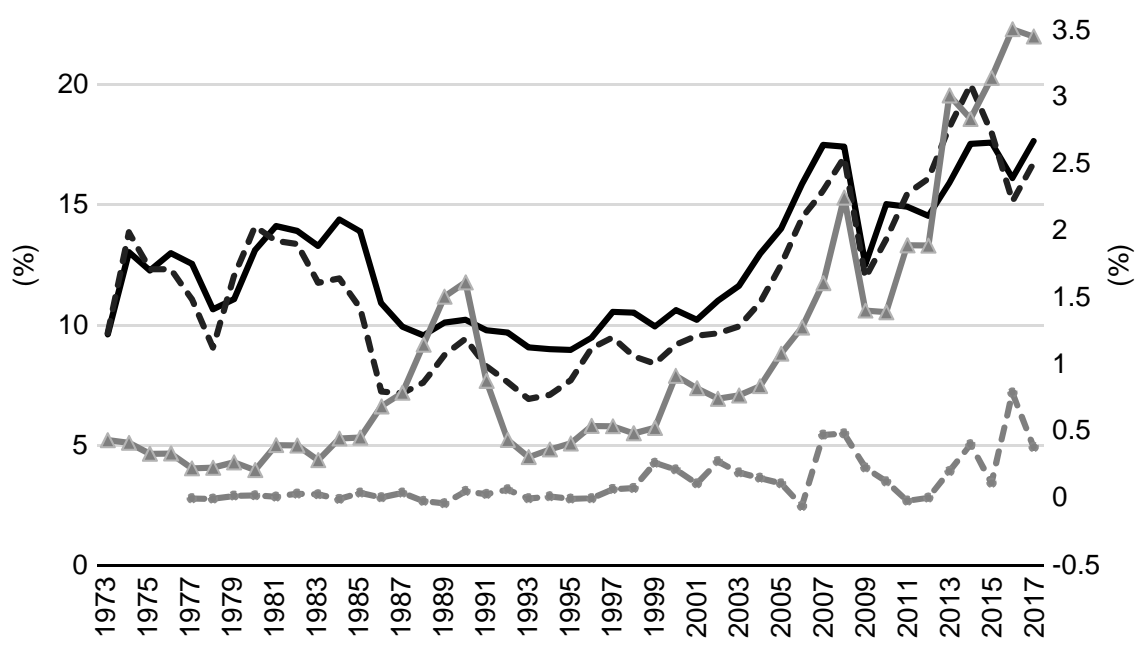

- Exports of goods and services (\% of GDP)

- - Imports of goods and services (\% of GDP)

- Foreign direct investment, net outflows (\% of GDP, right axis)

$\ldots$ - Foreign direct investment, net inflows (\% of GDP, right axis)

Figure 5.1 Value of Japan's Trade and FDI as a Share of GDP (\%) FDI = foreign direct investment, GDP $=$ gross domestic product.

Source: World Bank (2019), World Development Indicators 2019. Washington, DC: World Bank. https://databank.worldbank.org/source/world-development-indicators (accessed 19 May 2019).

effect of globalisation is likely to promote firms' efforts to improve productivity and develop new technologies, thereby increasing economic welfare.

Yet, in practice, a rise in anti-globalisation sentiment and protectionism can be observed across the world. One reason for the anti-globalisation sentiment is likely that the impact of globalisation is highly heterogeneous across firms and workers: globalisation creates winners and losers. As shown in Figure 5.2, in Japan for example, both the number and the share of workers in the manufacturing sector have been declining since the early 1990s (with the number falling by 4.8 million and the share by 7.2 percentage points from 1990 to 2012 ). On the other hand, the manufacturing share of real gross domestic product (GDP) has remained relatively stable, suggesting that labour productivity in manufacturing has been increasing relative to that in the service sector. ${ }^{1}$ The figure also implies that many manufacturing workers lost their jobs and were forced to move into the service sector, where labour productivity is not increasing and pay is less likely to increase, while workers who stayed in the manufacturing sector, where labour productivity is increasing, are relatively well paid. 

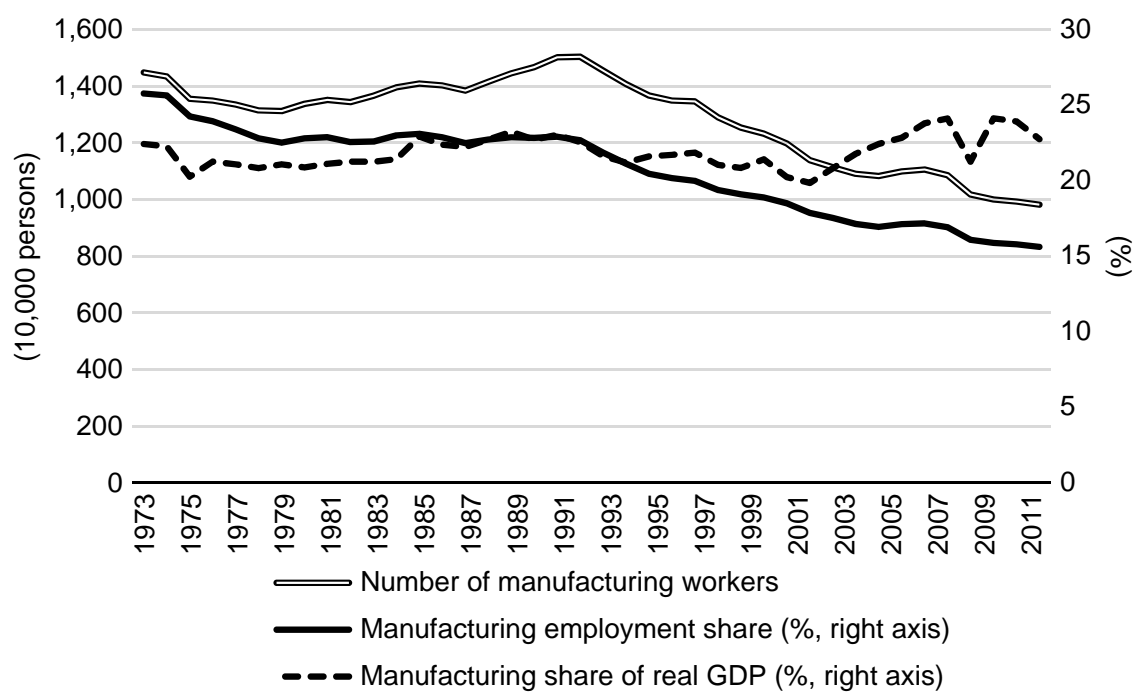

Figure 5.2 Employment and Value Added in the Japanese Manufacturing Sector. Note: GDP = gross domestic product. Source: RIETI (2015) JIP J IP Database 2015. Tokyo: Research Institute of Economy, Trade and Industry. https://www.rieti.go.jp/en/database/ JIP2015/index.html (accessed l April 2019).

Moreover, many previous studies suggest that although internationalised firms outperform others by a wide margin, the number of such firms is very small compared with the total number of firms. Furthermore, a large part of international trade is conducted by a very small number of top exporters (multinational firms in most cases). On the other hand, firms - particularly less productive ones facing import competition from low-wage countries are more likely to exit or shrink, and workers employed in such firms or industries are likely to lose their jobs. Within an internationalised firm, labour demand tends to shift away from unskilled workers towards skilled workers as firms get more involved in the international division of labour via trade and FDI. Thus, in developed countries, while globalisation may benefit skilled workers, unskilled workers are more likely to be worse off. Therefore, many developed countries are facing the urgent policy issue of how to distribute the gains from globalisation so that everyone benefits.

Statistics in many developed countries, including Japan, show that (i) a huge productivity gap exists across firms and the gap seems to be persistent; (ii) manufacturing employment has been declining while employment in the services sector has been increasing; and (iii) labour demand has been shifting away from unskilled workers towards skilled workers, resulting in substantial wage gaps across workers. Although these changes are partly attributable to globalisation, technological change is another important factor. These two factors - trade and technology - are intertwined and affect firm performance and the labour market. 
It is therefore important to note that it is extremely difficult to decompose the various changes into those resulting from globalisation and those caused by technological change.

This caveat notwithstanding, the aim of this paper is to derive the economic consequences of the expansion of international trade/investment with a focus on firm performance and the labour market, and to discuss the implications for policies to assist firms in their global activities and promote economic growth. The paper focuses primarily on evidence from Japan, mainly based on microdata such as firm- or establishment-level data. In particular, the following three aspects of globalisation are examined: exports, imports, and FDI. Linked these three aspects, the impact of 'offshoring' - defined as both international insourcing (offshore production and imports from overseas affiliates) and international outsourcing (imports from non-affiliated foreign firms) - is also discussed. While international migration is another aspect of globalisation, this aspect is not covered in this paper, partly because of the lack of such studies for Japan.

The findings of many previous studies suggest that globalisation - such as increases in exports, imports, and FDI - to some extent create winners and losers amongst firms and workers. A widening gap in productivity and wages has been observed in many countries. However, previous studies also show that the magnitude of the impact that is directly attributable to globalisation is quite limited. Although the empirical evidence on Japan is more or less consistent with that on other developed countries, noteworthy observations for Japan are as follows. First, several empirical studies confirm a learning-by-exporting effect as firms tend to improve their productivity after they start exporting. However, such a learning effect is not always found for other countries. Second, increases in imports from China do not always have a significant negative effect on employment and value-added growth in Japan, which contrasts with results for the US and some European countries. A possible interpretation of the results for Japan is that they reflect a complementary relationship between Japan and China in global supply chains.

The findings for Japan suggest that both firms and governments should not take a negative approach towards globalisation. Rather, firms should invest in new technology and human capital to respond flexibly to the structural changes brought about by globalisation and technological change. The government should encourage investment in such intangible assets by firms that are striving to succeed in the global market.

The rest of the paper is organised as follows. The next section reviews the empirical evidence on the impact of globalisation on firm-level productivity and innovation. Turning to the labour market, Section 3 looks at the impact on employment, skill composition, and wages. Section 4 discusses the inter-industry impact of globalisation, while Section 5 concludes. Finally, the appendix provides a summary of key studies and their empirical findings on the impact of globalisation for Japan. 


\section{The impact of globalisation on firm productivity and innovation}

Many previous studies show that firms engaged in international business are larger, more productive, and more innovative. Firms are also likely to improve their productivity after starting exporting and/or overseas production. ${ }^{2}$

\subsection{Superior performance of internationalised firms}

As numerous studies have shown, more productive firms that can pay the fixed cost required to start exporting/FDI are more likely to become exporters/ multinationals (selection effect), and such internationalised firms are more likely to improve their productivity by learning from international markets (learning effect). Internationalised firms, therefore, are expected to perform better than others because of these two effects. As for Japanese firms, many studies confirm that internationalised firms tend to be more productive than domestic firms (e.g. Kimura and Kiyota, 2006; Tomiura, 2007; and Wakasugi et al., 2011). For example, Wakasugi et al. (2011) showed that exporting firms' total factor productivity (TFP) is $38 \%$ higher than that of non-exporting firms. They also showed that multinational firms' TFP is $31 \%$ higher than that of nonmultinational firms. Moreover, as predicted by Helpman, Melitz, and Yeaple (2004), firms engaged in both exporting and FDI show the highest productivity on average, followed by exporting firms and firms not engaged in exporting and FDI. ${ }^{3}$ Furthermore, firms that invest in more regions tend to be more productive (Tanaka, 2012a).

The superior performance of internationalised firms can be explained by the selection effect and the learning effect. In the case of Japan, Kimura and Kiyota (2006) and Todo (2011a) confirmed that both effects raise the productivity of exporting and/or FDI firms. As shown in Figure 5.3, in the case of Japan, export starters tend to show higher productivity growth than firms that do not start exporting. ${ }^{4}$ Although Wagner (2012) argued that previous studies on other countries did not always find a positive learning effect, in the case of Japan, many studies including the ones mentioned above, have found a positive learning effect. While firms are required to continuously improve their efficiency to survive competition in foreign markets, they can also learn foreign firms' best practices by entering foreign markets via exporting or FDI. They not only learn foreign competitors' marketing know-how and their products but also obtain feedback from foreign customers. As I will discuss in the next subsection, exporters tend to utilise such information obtained from foreign markets and develop their technological capability. Moreover, not only exporting but also importing may have a positive impact on firm productivity. By using cheaper and higher quality imported intermediate goods, firms may be able to be more cost-competitive and shift towards higher value-added processes. In the case of Japanese manufacturing firms, Hijzen, Inui, and Todo (2010) found that offshoring is likely to have a positive effect on productivity. While Ito, Tomiura, and Wakasugi (2011) 


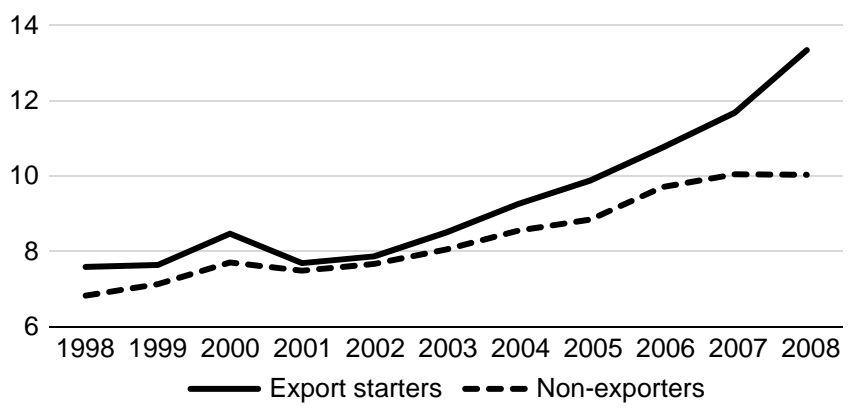

Figure 5.3 Average Labour Productivity of Export Starters and Non-Exporters. Source: METI (2012), Figure 3-1-3-3 (a).

Notes: 1 . The vertical axis shows the log of labour productivity. 2 . Export starters are firms that started exporting in 2001.

also found a productivity enhancing effect of offshoring, their results indicate that only firms that offshore both manufacturing and service tasks enjoy an improvement in productivity and that the level of firms' engagement in offshoring matters more than whether or not firms engage in offshoring.

Turning to the selection effect, although some studies provide evidence of such an effect for Japan, Todo (2011a) pointed out that the impact of productivity on firms' decision to export is economically negligible in size. According to his estimates, when the log of TFP improves by $50 \%$, the predicted probability that the average domestic firm becomes an exporter or an FDI firm increases by only $0.07 \%$. Todo $(2011 \mathrm{~b}$ ) argued that a significant number of highproductivity firms are not engaged in exporting and/or FDI. Todo (201 la) also pointed out that the exporting/FDI status of firms does not change easily. For example, more than $96 \%$ of non-exporters remain non-exporters the following year. The fact that only a few firms change their status over time implies that it is not easy to become an exporter or to expand overseas, even though firms' productivity is expected to increase after their status changes.

Why are some firms not engaged in international business even though they are productive? Possible reasons for the weak relationship between productivity and overseas expansion include a lack of information on foreign markets (information friction) and firms' risk-averse behaviour. For instance, Inui, Ito, and Miyakawa (2015) found that firms that have access to information on foreign markets via their main bank are more likely to start exporting. Todo and Sato (2014) found that firms with risk-tolerant and forward-looking managers are more likely to engage in international business. These studies suggest a need for policy support to potentially outward-oriented firms.

Although it is important to facilitate international activities by firms, particularly by promising and productive small and medium-sized enterprises, it is also widely observed in many countries that a large part of international trade is 
conducted by a very small number of internationalised firms. Wakasugi et al. (2011) showed that the largest 10\% of exporters accounted for 92\% of Japan's total exports (measured in value) and that this concentration ratio is comparable to that of the US and European countries. Similarly, Ito (2019) showed a huge gap in productivity between the top exporters and other exporters. Figure 5.4 shows the difference between the average productivity of exporting and nonexporting firms in the Japanese manufacturing sector. In the figure, exporters are further divided into four categories: top 10 exporters, permanent exporters, new exporters, and export exiters. The figure indicates that exporters as a whole are more productive than non-exporters (about $20 \%$ higher on average). It also shows that the top 10 exporters are much more productive than other exporters and that the average productivity of new exporters is not very high. It is well known that many export starters tend to stop exporting in a short period and it seems difficult for many new exporters to become permanent exporters (Inui, Ito, and Miyakawa, 2017). These findings suggest that another important policy issue is how to support new exporters to help them continue exporting to foreign markets in the long term to enjoy learning effects. For firms, one possible

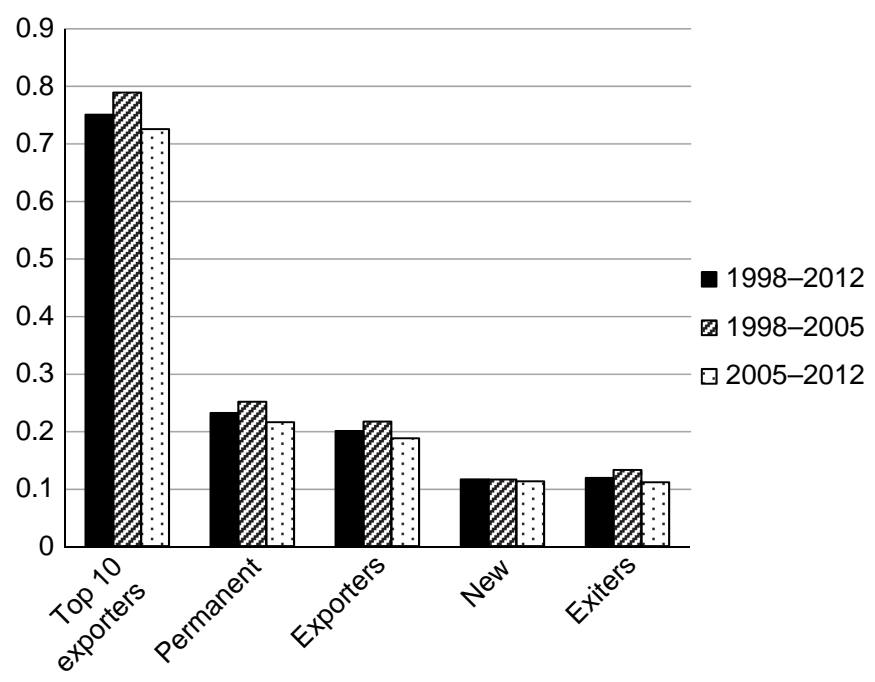

Figure 5.4 Difference in TFP between Exporters and Non-Exporters: Manufacturing Sector.

Source: Ito (2019), Figure 2 (b).

Notes: TFP $=$ total factor productivity. 1 . 'Top 10 exporters' denotes the 10 largest exporters in terms of export value. 2. 'Permanent' denotes firms exporting in at least three consecutive years, $t-1, t$, and $t+1$. 3. 'Exporters' denotes all exporting firms in year $t$. 4. 'New' denotes firms that did not export in year $t-1$ but started exporting in year $t$ and continued exporting in year $t+1.5$. 'Exiters' denotes firms that exported in years $t-1$ and $t$ but stopped exporting in year $t+1$. 


\section{Keiko Ito}

strategy might be to focus on niche markets; another might be to create transaction relationships with large global firms that help them to reduce the costs and risks involved in serving overseas markets. Reducing information frictions and facilitating risk management are areas in which the government could take some policy action.

\subsection{Bidirectional causal relationship between innovation and internationalisation}

Another issue that has been extensively investigated in the literature is the relationship between firms' decisions on exporting and on innovation. A substantial number of studies has shown a bidirectional causal relationship between firm innovation and export activity or complementarity between innovation and exporting (for empirical evidence on Japanese firms, see, for example, Ito and Lechevalier (2010) and Ito and Tanaka (2016)). ${ }^{5}$

While innovative firms are more likely to become exporters, firms serving international markets are also more likely to increase innovation activities because of knowledge spillovers from foreign competitors and partners as well as competitive pressures in those markets. Haneda and Ito (2014), employing the innovation accounting' framework proposed by Mairesse and Mohnen (2002), found that Japanese firms with R\&D establishments abroad show the best innovation performance compared with all other types of firms. More specifically, although international activities do not necessarily raise the probability of innovation, i.e. whether a firm successfully develops a new product, new products tend to account for a much larger share of sales in the case of firms engaged in international activities. In other words, firms engaged in international activities are more likely to develop new products that sell well. Haneda and Ito (2014) suggested that information/knowledge obtained from international markets plays an important role in this context. This can be interpreted as an effect of learning from foreign markets.

Haneda and Ito (2014) also showed that a significant part of the higher innovation performance of internationally active firms can be explained by greater intra-firm knowledge spillovers, R\&D intensity, perceived competitive pressure, and proximity to basic research. Highlighting the importance of knowledge spillovers from firms in foreign markets, Branstetter (2006) and Yashiro and Hirano (2010) argued that gathering information from foreign markets via exporting/FDI significantly raises firms' technological capabilities.

Also focusing on international knowledge spillovers, Ito et al. (2019) examined the relationship between patent applications by Japanese firms and their position in global value chains, which is measured using the Inter-Country Input-Output Tables of the Organisation for Economic Co-operation and Development. The authors assumed that industries with higher network centrality receive more knowledge spillovers because they are connected to more countries and industries. The study found that exporters in sectors that are more central in the forward linkage network (i.e. the downstream input linkage 
network) tend to file for more high-quality patents, as measured by the citationweighted number of patent applications. Such exporters in sectors with higher forward centrality are interpreted as being key suppliers, and they tend to be more innovative. The finding suggests that the position within global value chains is another important factor determining the innovative capability of firms.

As suggested by Haneda and Ito (2014), competitive pressures may make firms more innovative. However, fierce competition potentially also dampens firms' investment in innovation activities, because market competition is likely to reduce firms' profits. Examining the innovation response of Japanese firms to intensified import competition from China during 1995-2010, Yamashita and Yamauchi (2020) found that firms that exported and/or imported filed for more patents in response to the increased import competition from China. However, Chinese import competition adversely affected the quality of innovation as measured by citations. While Chinese import competition did not have any significant impact on patent applications by domestic firms which are not engaged in exports/imports, it had a negative impact on their R\&D expenditure. ${ }^{6}$ Therefore, evaluating the impact of import competition from China on innovation output by Japanese firms is not straightforward. However, what seems safe to say is that the competition faced by firms engaged in international activities compels them to make greater efforts to innovate. Meanwhile, the negative impact on the quality of innovation (as measured by citations) is an issue that deserves further scrutiny in future research.

\section{Globalisation and the labour market}

Another hotly debated issue in many countries has been the impact of globalisation on employment and wages. In Japan, as shown above, the share of manufacturing workers has declined drastically since the early 1990s, when Japanese firms started expanding offshore production and increasing imports. Moreover, standard international trade theory predicts that trade liberalisation is likely to accelerate specialisation in capital- and skill-intensive production in developed countries, while unskilled labour-intensive production will be moved to developing countries. Therefore, for developed countries, increases in exports are likely to have a positive impact on demand for skilled workers on the one hand, and increases in imports are likely to have a negative impact on demand for unskilled workers on the other. Against this background, this section discusses the impact of imports and offshoring as well as exports on changes on domestic employment, wages, and the skill composition of workers.

\subsection{Impact on domestic employment}

Starting with the impact on domestic employment, several industry-level studies have examined the impact of imports and exports on employment in Japan. Using the decline in import prices as a measure of import competition, Tomiura (2003) found that import competition has a negative effect on domestic employment. 


\section{Keiko Ito}

However, imports are only one side of the coin and often go hand in hand with increases in exports. This is shown by factor content analyses based on input-output tables, which highlight that globalisation increases not only imports but also exports, so that the negative impact of globalisation on domestic employment has been rather limited (see, for example, Sakurai [2014]).

In recent years, the rapid increase in imports from China has been blamed as a major cause of the decline in manufacturing employment in the US. For example, Autor, Dorn, and Hanson (2013) estimated that the increase in imports from China explains about a quarter of the decline in manufacturing employment in the US. However, using Japanese prefecture-level data, Taniguchi (2019) conducted a similar analysis to that of Autor, Dorn, and Hanson (2013) and found that in Japan an increase in imports from China is positively associated with manufacturing employment. ${ }^{7}$ The reason for the positive impact of Chinese imports on employment in Japan is probably that industries importing from China increased their exports as well. The difference between Japan and the US potentially implies that Japanese imports from China are more likely to be complementary to, and not substitutes for, Japanese production and exports.

Studies based on firm-level data have also shown that the direct impact of globalisation on firm employment has been quite limited. Since increases in imports of intermediate inputs to a large extent are due to the expansion of overseas production by Japanese multinational enterprises (MNEs), Yamashita and Fukao (2010) examined the relationship between domestic employment and employment in overseas affiliates of Japanese manufacturing MNEs using parent-affiliate matched data. They did not find a statistically significant negative relationship. Meanwhile, following the research framework employed by Harrison and McMillan (2011), Kambayashi and Kiyota (2015) examined the effects of FDI on the domestic employment of Japanese manufacturing MNEs. They found that 'disemployment' (reductions in employment, especially in the manufacturing sector) in Japan is mainly driven by substitution between capital and labour rather than the reallocation of labour from Japan to overseas via FDI. ${ }^{8}$ Ando and Kimura (2017) also found that Japanese multinational firms which expand their foreign operations tend to increase domestic employment, mainly in the form of boosting headquarters services, and concluded that the globalisation of corporate activities contributes to the expansion of domestic employment by boosting complementary activities at home.

These studies suggest that domestic workers were not perfectly substituted for foreign workers embodied in imported goods. By shifting operations at home towards higher value-added processes which are complementary to offshored lower value-added processes, Japanese firms have been trying to sustain domestic employment but the composition of worker skills and occupations may have been changed substantially. I will return to this point in the next subsection.

While the above studies have suggested that the overseas expansion of Japanese MNEs did not have a significant negative impact on the domestic employment of the MNEs themselves, it may have had a negative impact on the employment of domestic firms acting as suppliers to MNEs. Taking domestic 
supplier-customer relationships into account, Ito and Tanaka (2014) examined the relationship between the overseas expansion of Japanese MNEs and the employment of domestic suppliers of these MNEs. However, they did not find any negative relationship and instead discovered that the relationship tends to be positive. The finding suggests that domestic suppliers selling to MNEs that are expanding overseas do not reduce employment more than firms not selling to MNEs.

Summing up, the studies on Japan suggest that we cannot conclude that globalisation has a negative impact on domestic employment. ${ }^{9}$

\subsection{Impact on skill composition}

Globalisation is likely to have differential effects on the domestic demand for labour in terms of the skills that workers possess and the tasks in which they engage. In particular, this differential impact on labour demand is likely to increase wage gaps across workers. This is borne out in studies showing that globalisation negatively affects certain types of workers in certain regions and/or industries. Generally speaking, in developed countries, low-skilled workers tend to be worse off while high-skilled workers tend to be better off as a result of globalisation. This section provides a summary of research findings on such heterogeneous effects of globalisation on the labour market in Japan.

The rapid and worldwide advances in trade liberalisation and the development of information and communication technologies since the 1990s have dramatically reduced the cost of the international division of labour or fragmentation of production. In production fragmentation, unskilled labour-intensive processes are located in low-wage developing countries, while skilled labour-, capital-, and knowledge-intensive processes are located in developed countries. Unskilled labour-intensive processes or tasks are increasingly moved offshore or outsourced to developing countries.

Therefore, fragmentation is expected to increase the demand for skilled workers in developed countries, and many studies confirm that increases in imports of intermediate inputs are positively associated with an increase in the skill intensity of production in developed countries. Ito and Fukao (2005), following the framework employed by Feenstra and Hanson (1996), showed that imports of intermediate inputs, particularly imports of relatively low-tech intermediate inputs from Asian countries, have led to an increase in the share of skilled workers in Japan's manufacturing sector. Ito and Fukao (2005) estimated that nearly half of the increase in the skilled worker share in Japan's manufacturing sector from 1988 to 2002 is attributable to the increase in the intra-industry division of labour with Asian countries. Similarly, Ahn, Fukao, and Ito (2008) and Yamashita (2008) found a positive relationship between intermediate input imports from Asia and skill intensity in Japan. Further, Kiyota and Maruyama (2017) concluded that offshoring has increased the demand for high-skilled workers in Japan. Studies based on firm-level data have also found strong evidence that the expansion of the overseas production of Japanese MNEs has 


\section{Keiko Ito}

increased the skill intensity of production at home (e.g. Head and Ries, 2002; Hayakawa et al., 2013). ${ }^{10}$

On the other hand, Tanaka (2012b) found that the share of temporary workers dispatched from staffing companies tends to increase after a firm becomes a multinational, although the number of workers at home does not decline. This is an interesting finding and may imply that globalised firms tend to utilise more temporary workers, the number of which firms can flexibly increase or reduce in response to economic conditions and/or the speed of technological developments. This result suggests that, in addition to the demand for skilled workers, globalisation appears to increase the need for a more flexible workforce.

\subsection{Impact on wages}

The previous section has shown considerable evidence that globalisation has increased the demand for skilled workers more than for unskilled workers. This demand shift towards skilled workers in turn has implications for the wage gap between skilled and unskilled workers. In fact, it is now well known that the demand shift towards skilled workers has been larger and more significant within industries and within firms than between industries. Previous research has highlighted that the demand shift within industries and firms is attributable to skill-biased technological change and offshoring. For instance, one of the pioneering studies on the US, Feenstra and Hanson (1999), found that both skillbiased technological change and offshoring have contributed to the increased wage gap between skilled and unskilled workers in the US, although the impact of skill-biased technological change was larger than that of offshoring.

As for Japan, Sasaki and Sakura (2004) and Sakurai (2014) confirmed that the wage gap between skilled and unskilled workers has been increasing, albeit slowly, and that international trade (i.e. import competition and offshoring) have contributed to this increase in the wage gap to some extent. Although these two studies took different approaches, both concluded that the impact of offshoring was almost the same as, or slightly larger than, the impact of skill-biased technological change. Endoh (2018), analysing employer-employee-matched data for Japan, also found that offshoring has contributed to the widening of the wage gap.

However, the widening wage gaps at the macro level observed in many countries are because of a number of reasons, and the contribution of globalisation appears to be modest (Helpman, 2016). This is the conclusion suggested by, for example, Burstein and Vogel (2017), who estimated the impact of globalisation on the wage gap using a trade model and data for 60 countries around the world covering the period from 2005 to 2007 . They measured the impact of trade by comparing the estimated wage gap in the case with international trade and without international trade (i.e. trade costs are infinity). They found that international trade increased the wage gap between skilled and unskilled workers by $5.1 \%$ on average, although the impact varied across countries depending on various country characteristics such as the trade openness and comparative 
advantage. For the US and Japan, the impact was about 2\%. Burstein and Vogel (2017) as well as Burstein, Morales, and Vogel (2019) suggested that the magnitude of the impact of international trade depends on each country's trade share and the size of the elasticity of substitution across workers with different skills. Given the estimated trade shares and elasticity of substitution based on actual trade data, these studies confirmed that international trade impacted wage inequality but had only moderate effects.

As reviewed by Helpman (2016), various factors affect wage inequality, including labour supply changes, technological changes, firm and worker heterogeneity, and labour market frictions. While the impact of globalisation on wage inequality has been extensively investigated, incorporating these various factors, quantitative estimates produced so far have revealed that the effects of globalisation explain only a fraction of the actual rise in wage inequality. For example, Autor (2014) showed that the college wage premium in the US doubled from $48 \%$ in 1979 to $96 \%$ in 2012 ; i.e. in 2012 , a college graduate earned $96 \%$ more than a high-school graduate. Thus, compared with the increase in the college wage premium, the impact of trade on the wage gap estimated by Burstein and Vogel (2017) is very small. On the other hand, in the case of Japan, Kawaguchi and Mori (2016) showed that the college wage premium decreased by 1 percentage point from 1986 to $2008 .{ }^{11}$ Therefore, while the impact of trade on the wage gap may have been quite substantial in Japan, other factors, presumably the rapid increase in the supply of college graduates, appear to have more than offset the widening of the wage gap due to trade.

More recently, a growing number of researchers have suggested that the shift in labour demand is not actually from unskilled towards skilled workers. Rather, they argue, it is the demand for middle-skilled workers that is negatively affected by globalisation, while demand for low-skilled and high-skilled workers is increasing. The reason is that middle-skilled workers tend to engage in routine tasks that are easily computerised and/or offshored. On the other hand, nonroutine cognitive analytical/interpersonal and non-routine manual physical tasks are not easily offshored, i.e. the 'offshorability' of such non-routine tasks is low. Therefore, such tasks tend to remain at home, and demand for high- and lowskilled workers engaged in these tasks has been increasing at home (e.g. Oldenski, 2012; Autor and Dorn, 2013; Becker, Ekholm, and Muendler, 2013; and Goos, Manning, and Salomons, 2014).

In the case of Japan, there are no rigorous analyses on the relationship between globalisation and labour demand at the detailed task level because of lack of data. However, employing factor content analysis using input-output tables and industry-level employment data, Tomiura, Wakasugi, and Zhu (2014) showed that Japan's net exports of routine tasks significantly decreased from 1995 to 2005. The finding suggests that globalisation has contributed to job polarisation in Japan. However, studies on European countries such as Becker, Ekholm, and Muendler (2013) and Baumgarten, Geishecker, and Görg (2013) argued that the effects of globalisation on wage gaps between workers engaged in different tasks are quite complex and depend on workers' educational attainment, skill 


\section{Keiko Ito}

types, the degree of task 'offshorability,' and the size and scope of firms' international activities.

In sum, many previous studies, including studies on Japan, show that globalisation has affected domestic employment, the composition of workers, and wage gaps across workers. More specifically, offshoring has shifted labour demand away from low-skilled and/or medium-skilled workers towards highskilled workers, thereby increasing the wage gaps across different types of workers. However, relative to actually observed macro-level changes in employment and wages, it is generally believed that the direct impact of globalisation has been rather limited. Of course, it should be noted that it is difficult to perfectly separate out the impact of globalisation from other effects such as those caused by technological change (and, such as in the case of Japan, changes in the labour supply due to demographic changes).

\section{Inter-industry impact of globalisation}

The studies reviewed in the preceding sections have suggested that globalisation has not necessarily had a large negative impact on firm performance or the labour market. More globalised firms tend to be more productive and more incentivised to innovate, resulting in higher wages. Although globalisation has increased wage gaps across workers, the impact has been rather limited. However, most of the studies reviewed so far examine the direct impact of globalisation on the industries or firms involved and do not take inter-industry effects into account. While globalisation is likely to have a positive impact on 'better' (more internationalised and more innovative) firms and on 'better' (more skilled) workers, such effects may change the composition of activities and worker types within industries/firms. Moreover, even though the micro-level impact has been limited, it is possible that effects are amplified via inter-industry or inter-firm relationships, leading to significant structural changes such as the sharp decline in manufacturing employment shown in Figure 5.1 above. $^{12}$

Therefore, by changing firms' behaviour and the composition of the workforce, globalisation may have accelerated structural changes. This section discusses the inter-industry effects of globalisation.

\subsection{Servicification or changes in activities within manufacturing firms}

One of the aspects related to the offshoring of production processes and tasks is the increased 'servicification' of manufacturing firms in many developed countries. Relatively low skill-intensive and routine task-intensive processes are easily offshored, and these processes tend to be the 'manufacturing' part of the supply chain. Therefore, manufacturing MNEs tend to move such manufacturing processes offshore and concentrate on high skill-intensive and non-routine taskintensive services at home. This is illustrated, for example, by a study by Ito and Ikeuchi (2017), who, using Japanese firm-establishment matched data, found 
that firms are more likely to shut down domestic establishments in more routine task-intensive industries after they became a multinational. They also found that establishments in non-routine task-intensive industries tend to show higher employment growth. While not all non-routine task-intensive industries are service industries, their study suggests that expansion abroad may have led to the restructuring of domestic activities and may to some extent have driven the 'servicification' of manufacturing firms and the economy overall. ${ }^{13}$

\subsection{Propagation of the impact of increased imports from China across industries}

In the US, some researchers such as Acemoglu et al. (2016) have argued that import competition from China has a significant impact on economy-wide employment when the indirect effects of globalisation through input-output linkages are taken into account. Acemoglu and his research group also examined how shocks in the form of increased imports from China propagate across industries via input-output linkages. For example, Acemoglu, Akcigit, and Kerr (2016) showed that increases in imports from China in an industry reduce valueadded growth in upstream industries, although the impact on downstream industries is not significant. ${ }^{14}$

In the case of Japan, Fabinger, Shibuya, and Taniguchi (2017) examined the impact of increases in imports from China following the framework employed by Acemoglu, Akcigit, and Kerr (2016). Their results were somewhat different from those obtained by Acemoglu Akcigit, and Kerr (2016). That is, while the studies found a significant negative impact on upstream industries for both Japan and the US, increases in imports from China have a positive effect on value-added growth in downstream industries in Japan but no significant impact in the US. Therefore, while in the US increases in imports from China only have a negative impact, in the case of Japan they have a positive impact on downstream industries. While Fabinger, Shibuya, and Taniguchi (2017) did not investigate the reasons for this difference between Japan and the US, one possible interpretation is that the impact of imports differs depending on the relationship between imports and domestic production. That is, while Chinese imports likely are more complementary to domestic production in Japan, they are more likely to be substitutes in the US.

To illustrate this point, Figure 5.5 shows the value of trade between China on the one hand and the US or Japan on the other for different types of goods. The US has a trade deficit with China both in final and in intermediate goods, while Japan has a trade surplus with China in intermediate goods. This pattern suggests that Japan exports a substantial amount of intermediate goods to China, implying that Japan and China are more heavily involved in a division of labour between each other than the US and China. This difference between Japan and the US may explain the different results of the empirical studies on these two countries. 


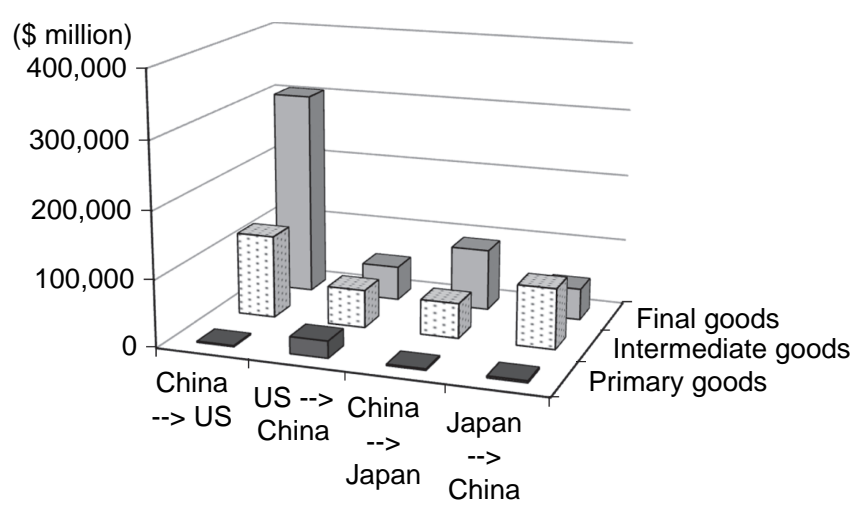

Figure 5.5 Value of China-US and China-Japan Trade by Type of Goods, 2016. Source: RIETI (2015) RIETI Trade Industry Database 2017 (RIETI-TID2017). Tokyo: Research Institute of Economy, Trade and Industry. https://www.rieti.go.jp/en/projects/rieti-tid/ (accessed 17 January 2019).

Note: US = United States.

\section{Summary and policy implications}

This paper summarised the major findings of and arguments in the literature on the impact of globalisation on firm performance and the labour market, focusing on the case of Japan.

Similar to their counterparts in many other developed countries, Japanese firms that are engaged in international trade and FDI outperform other domestic firms. However, only a small number of firms is directly engaged in international business, while most firms operate only in the domestic market. A noteworthy observation for Japan is that several empirical studies confirm a learning-byexporting effect, even though such a learning effect is not always found for other countries. Yet, there is a huge performance gap not only between exporters and non-exporters but also amongst exporters - such as between top exporters and new exporters. These findings suggest that providing support to firms trying to serve foreign markets could be an important way to improve the performance of the economy overall. Such support could take the form of policies to reduce information frictions and the risks involved in overseas business. Moreover, given that many studies show that international activities and innovation are complementary, it might be useful to devise packages that combine both policies to promote science and technology and policies to promote international trade.

As for the impact of globalisation on the labour market, many studies have shown that competition from imports as well as offshoring have shifted labour demand towards skilled workers, resulting in a widening of the wage gap between skilled and unskilled workers. However, although some types of workers, or workers in certain occupations or industries or regions, may be severely 
affected by globalisation, the contribution of globalisation to the widening wage gap is considered to be quite limited. Moreover, in the case of Japan, there is no strong evidence that increases in imports from China have significantly reduced domestic employment in industries and regions facing import competition from China, which differs from results for the US. The difference between Japan and the US potentially implies that imports from China are more likely to be complementary to domestic production in Japan, while they are more likely to be substitutes in the US.

The findings summarised in this paper suggest that many Japanese firms still have the potential to grow by learning from foreign markets and that Japanese firms and industries are likely to benefit from globalisation in the case where domestic production is complementary to imports from foreign countries. As for the impact of globalisation on the labour market, while some types of workers and firms do not enjoy significant benefits from globalisation, previous studies have shown that the magnitude of the impact that is directly attributable to globalisation is quite limited.

That said, it is possible that globalisation has accelerated structural changes in the Japanese economy. The share of manufacturing workers has shrunk dramatically, and more workers are now engaged in labour-intensive service industries, where labour productivity is relatively low. Looking ahead, it is likely that globalisation and technological change will be even more intertwined than they have been so far, meaning that both may have an even greater effect on firm performance and the labour market. This means that it is of the utmost importance for firms in Japan to invest in new technology and human capital to respond flexibly to the structural changes brought about by globalisation and technological change. However, various statistics indicate that Japan is lagging other developed economies in terms of investment in intangible assets such as organisational capital and human capital (see INTAN-Invest (2019) for the US and European countries and RIETI (2015) for Japan). Therefore, it may be useful to provide policy support to increase investment, particularly investment in intangible assets, by firms that are striving to succeed in the global market. Japanese firms need to continue investing in $\mathrm{R} \& \mathrm{D}$, human capital, global production and distribution networks, new technology, etc., to benefit from the globalised economy. Amongst such investment, investment in human capital is of particular importance, as it helps workers respond to the structural changes brought about by globalisation and hence can help to address the growing anti-globalisation sentiment and protectionism mentioned at the outset.

\section{Notes}

1 Baily and Bosworth (2014) and Fort, Pierce, and Schott (2018) showed a similar trend for manufacturing in the United States (US).

2 There is a large body of literature on the relationship between globalisation and firms' performance. See previous literature reviews such as those by Greenaway and Kneller (2007); Wagner (2007, 2012); and Hayakawa, Machikita, and Kimura (2012). 
3 Wakasugi et al. (2011) and many other studies have shown that firms engaged in international activities such as exporting and FDI are not only more productive but also outperform other firms in various other respects. For instance, such firms are larger, more R\&D-intensive, more capital- and skill-intensive, and pay higher wages. As for the wage premium of exporters, Ito (2017) found that, after controlling for worker characteristics, the premium is much larger for smaller plants than for larger ones. On the other hand, Tanaka (2018) concluded that most of the wage premium of exporting and/or FDI firms can be accounted for by worker characteristics. These results may suggest that internationalised firms, particularly large internationalised firms, tend to employ more skilled workers, resulting in higher performance and higher wages.

4 The same study on which Figure 5.3 is based (METI, 2012) provided a similar figure comparing firms that started FDI (rather than exports) and firms that did not. The figure indicates that FDI starters similarly show higher productivity growth after starting FDI.

5 Regarding other countries, Damijan, Kostevc, and Polanec (2010), for example, examined the bidirectional causal relationship in the case of Slovenia.

6 Yamashita and Yamauchi (2020) employed a similar approach to that used by Bloom, Draca, and Van Reenen (2016) for European firms and by Autor et al. (2016) for US firms. While Bloom, Draca, and Van Reenen (2016) found a positive impact of import competition from China on patent applications by European firms, Autor et al. (2016) obtained the opposite result for US firms.

7 Studies for European countries (e.g. Dauth, Findeisen, and Suedekum, 2014; Balsvik, Jensen, and Salvanes, 2015; and Donoso, Martin, and Minondo, 2015) obtained results consistent with those of Autor, Dorn, and Hanson (2013) for the US.

8 Analysing data for US MNEs, Harrison and McMillan (2011) concluded that increases in offshoring by US MNEs reduced manufacturing employment at home, but the magnitude was very limited.

9 According to Wagner (2011), many studies on developed countries have found no statistically significant relationship between FDI and employment at home. Instead, several studies have found a positive relationship.

10 The definition of 'skilled' or 'unskilled' workers differs across studies. For instance, Ito and Fukao (2005) defined skilled workers as workers whose profession is classified as 'professional and technical' or 'managerial and administrative.' Meanwhile Ahn et al. (2008) and Kiyota and Maruyama (2017) defined 'skill' in terms of educational attainment, while Yamashita (2008), Head and Ries (2002), and Hayakawa et al. (2013) defined workers in terms of whether they are engaged in production or non-production activities and regard non-production workers as 'skilled' workers.

11 In contrast, for the US, Kawaguchi and Mori (2016) estimated that the college wage premium increased by 22 percentage points from 1986 to 2008 .

12 In the case of other developed countries, there is some empirical evidence that offshoring and import competition have negatively affected the demand for middle-skilled workers in the manufacturing sector and have forced such workers into low-wage service jobs. See, for example, Ebenstein et al. (2014); Goos, Manning, and Salomons (2014); and Keller and Utar (2016).

13 Bernard, Smeets, and Warzynski (2017) and Crozet and Milet (2017) showed that the switch to the service sector or 'servicification' of manufacturing firms explains a significant part of the reduction of manufacturing employment and sales in Denmark and France, respectively.

14 In the case of the US, imports from China have a significant negative impact on overall employment because of both direct and indirect effects. Acemoglu et al. 
(2016) estimated that about 2.0 million-2.4 million workers in the US manufacturing sector lost their jobs during 1999-2011 because of import competition from China.

\section{References}

Acemoglu, D., U. Akcigit, and W. Kerr (2016), 'Networks and the Macroeconomy: An Empirical Exploration', NBER Macroeconomics Annual, 30(1), pp.273-335.

Acemoglu, D., D. Dorn, G.H. Hanson, and B. Price (2016), 'Import Competition and the Great US Employment Sag of the 2000s', Journal of Labor Economics, 34(S1), pp.S141-S198.

Ahn, S., K. Fukao, and K. Ito (2008), 'Outsourcing in East Asia and Its Impact on the Japanese and Korean Labour Markets', OECD Trade Policy Papers, No. 65. Paris: Organisation for Economic Co-operation and Development.

Ando, M. and F. Kimura (2017), 'Job Creation and Destruction at the Levels of Intra-firm Sections, Firms, and Industries in Globalization: The Case of Japanese Manufacturing Firms', RIETI Discussion Paper, 17-E-100. Tokyo: Research Institute of Economy, Trade and Industry.

Autor, D.H. (2014), 'Skills, Education, and the Rise of Earnings Inequality Among the "Other 99 Percent", Science, 344(6186), pp.843-851.

Autor, D.H. and D. Dorn (2013), 'The Growth of Low-Skill Service Jobs and the Polarization of the US Labor Market', American Economic Review, 103(5), pp.1553-1597.

Autor, D.H., D. Dorn, and G.H. Hanson (2013), 'The China Syndrome: Local Labor Market Effects of Import Competition in the United States', American Economic Review, 103(6), pp.2121-2168.

Autor, D., D. Dorn, G.H. Hanson, G. Pisano, and P. Shu (2016), 'Foreign Competition and Domestic Innovation: Evidence from U.S. Patents', NBER Working Paper, No. 22879. Cambridge, MA: National Bureau of Economic Research.

Baily, M.N. and B.P. Bosworth (2014), 'US Manufacturing: Understanding Its Past and Its Potential Future', Journal of Economic Perspectives, 28(1), pp.3-26.

Balsvik, R., S. Jensen, and K.G. Salvanes (2015), 'Made in China, Sold in Norway: Local Labor Market Effects of an Import Shock', Journal of Public Economics, 127, pp.137-144.

Baumgarten, D., I. Geishecker, and H. Görg (2013), 'Offshoring, Tasks, and the Skill-Wage Pattern', European Economic Review, 61, pp.132-152.

Becker, S.O., K. Ekholm, and M.A. Muendler (2013), 'Offshoring and the Onshore Composition of Tasks and Skills', Journal of International Economics, 90(1), pp.91-106.

Bernard, A.B. and J.B. Jensen (1999), 'Exceptional Exporter Performance: Cause, Effect, or Both?', Journal of International Economics, 47(1), pp.1-25.

Bernard, A.B., V. Smeets, and F. Warzynski (2017), 'Rethinking Deindustrialization', Economic Policy, 32(89), pp.5-38.

Bloom, N., M. Draca, and J. Van Reenen (2016), 'Trade Induced Technical Change? The Impact of Chinese Imports and Innovation, IT and Productivity', The Review of Economic Studies, 83(1), pp.87-117. 


\section{Keiko Ito}

Branstetter, L. (2006), 'Is Foreign Direct Investment A Channel of Knowledge Spillovers? Evidence from Japan's FDI in the United States', Journal of International Economics, 68(2), pp.325-344.

Burstein, A. and J. Vogel (2017), 'International Trade, Technology, and the Skill Premium', Journal of Political Economy, 125(5), pp.1356-1412.

Burstein, A., E. Morales, and J. Vogel (2019) 'Changes in Between-Group Inequality: Computers, Occupations, and International Trade', American Economic Journal: Macroeconomics, 11(2), pp.348-400.

Crozet, M. and E. Milet (2017), 'The Servitization of French Manufacturing Firms: Outsourcing, Servitization, and the Future of Industry,' in L. Fontagné and A. Harrison (eds.) The Factory-Free Economy: Outsourcing, Servitization, and the Future of Industry. Oxford: Oxford University Press, pp.111-135.

Damijan, J.P., C. Kostevc, and S. Polanec (2010), 'From Innovation to Exporting or Vice Versa?', The World Economy, 33(3), pp.374-398.

Dauth, W., S. Findeisen, and J. Suedekum (2014), 'The Rise of the East and the Far East: German Labor Markets and Trade Integration', Journal of the European Economic Association, 12(6), pp.1643-1675.

Donoso, V., V. Martin, and A. Minondo (2015), 'Do Differences in the Exposure to Chinese Imports Lead to Differences in Local Labour Market Outcomes? An Analysis for Spanish Provinces', Regional Studies, 49(10), pp.1746-1764.

Ebenstein, A., A. Harrison, M. McMillan, and S. Phillips (2014), 'Estimating the Impact of Trade and Offshoring on American Workers Using the Current Population Surveys', The Review of Economics and Statistics, 96(4), pp.581-595.

Endoh, M. (2018), 'The Effect of Import Competition on Wages in the Japanese Manufacturing Sector', Asian Economic Papers, 17(1), pp.46-67.

Fabinger, M., Y. Shibuya, and M. Taniguchi (2017), 'International Influences on Japanese Supply Chains', RIETI Discussion Paper, 17-E-022. Tokyo: Research Institute of Economy, Trade and Industry.

Feenstra, R.C. and G. Hanson (1996), 'Globalization, Outsourcing, and Wage Inequality', The American Economic Review, 86(2), pp.240-245.

Feenstra, R.C. and G. Hanson (1999), 'The Impact of Outsourcing and HighTechnology Capital on Wages: Estimates for the United States, 1979-1990', The Quarterly Journal of Economics, 114(3), pp.907-940.

Fort, T.C., J.R. Pierce, and P.K. Schott (2018), 'New Perspectives on the Decline of US Manufacturing Employment', Journal of Economic Perspectives, 32(2), pp.47-72.

Goos, M., A. Manning, and A. Salomons (2014), 'Explaining Job Polarization: Routine-Biased Technological Change and Offshoring', American Economic Review, 104(8), pp.2509-2526.

Greenaway, D. and R. Kneller (2007), 'Firm Heterogeneity, Exporting and Foreign Direct Investment', The Economic Journal, 117(517), pp.F134-F161.

Haneda, S. and K. Ito (2014), 'Modes of International Activities and the Innovativeness of Firms: An Empirical Analysis Based on the Japanese National Innovation Survey for 2009', Economics of Innovation and New Technology, 23(8), pp.758-779.

Harrison, A. and M. McMillan (2011), 'Offshoring Jobs? Multinationals and U.S. Manufacturing Employment', The Review of Economics and Statistics, 93(3), pp.857-875. 
Hayakawa, K., T. Machikita, and F. Kimura (2012), 'Globalization and Productivity: A Survey of Firm-Level Analysis', Journal of Economic Surveys, 26(2), pp.332-350. Hayakawa, K., T. Matsuura, K. Motohashi, and A. Obashi (2013), 'TwoDimensional Analysis of the Impact of Outward FDI on Performance at Home: Evidence from Japanese Manufacturing Firms', Japan and the World Economy, 27(C), pp.25-33.

Head, K. and J. Ries (2002), 'Offshore Production and Skill Upgrading by Japanese Manufacturing Firms', Journal of International Economics, 58(1), pp.81-105.

Helpman, E. (2016), 'Globalization and Wage Inequality', NBER Working Paper, No. 22944. Cambridge, MA: National Bureau of Economic Research.

Helpman, E., M.J. Melitz, and S.R. Yeaple (2004), 'Export Versus FDI with Heterogeneous Firms', The American Economic Review, 94(1), pp.300-316.

Hijzen, A., T. Inui, and Y. Todo (2010), 'Does Offshoring Pay? Firm-Level Evidence from Japan', Economic Inquiry, 48(4), pp.880-895.

INTAN-Invest (2019), INTAN-Invest Database, Edition January 2019. http:// www.intaninvest.net/intan-invest-data/download-data/ (accessed 7 April 2019).

Inui, T., K. Ito, and D. Miyakawa (2015), 'Overseas Market Information and Firms' Export Decision', Economic Inquiry, 53(3), pp.1671-1688.

Inui T., K. Ito, and D. Miyakawa (2017), 'Export Experience, Product Differentiation and Firm Survival in Export Markets', The Japanese Economic Review, 68(2), pp.217-231.

Ito, K. (2017), 'Wage Premium of Exporting Plants in Japan: Do Plant and Firm Size Matter?', RIETI Discussion Paper, No. 17-E-115. Tokyo: Research Institute of Economy, Trade and Industry.

Ito, K. (2019), 'Exporter Dynamics and Productivity Dispersion within Industry', ERIA Discussion Paper, No. 20. Jakarta: Economic Research Institute for ASEAN and East Asia.

Ito, K. and K. Fukao (2005), 'Physical and Human Capital Deepening and New Trade Patterns in Japan', in T. Ito and A. Rose (eds.) International Trade in East Asia. Chicago: University of Chicago Press, pp.7-49.

Ito, K. and K. Ikeuchi (2017), 'Overseas Expansion and Domestic Business Restructuring in Japanese Firms', The Developing Economies, 55(2), pp.75-104.

Ito, K., K. Ikeuchi, C. Criscuolo, J. Timmis, and A. Bergeaud (2019), 'Global Value Chains and Domestic Innovation', RIETI Discussion Paper, No. 19-E-028. Tokyo: Research Institute of Economy, Trade and Industry.

Ito, K. and S. Lechevalier (2010), 'Why Some Firms Persistently Out-Perform Others: Investigating the Interactions Between Innovation and Exporting Strategies', Industrial and Corporate Change, 19(6), pp.1997-2039.

Ito, K. and A. Tanaka (2014), 'The Impact of Multinationals' Overseas Expansion on Employment at Suppliers at Home: New Evidence from Firm-Level Transaction Relationship Data for Japan', RIETI Discussion Paper, No. 14-E-011. Tokyo: Research Institute of Economy, Trade and Industry.

Ito, B. and A. Tanaka (2016), 'External R\&D, Productivity, and Export: Evidence from Japanese Firms', Review of World Economics, 152(3), pp.577-596.

Ito, B., E. Tomiura, and R. Wakasugi (2011), 'Offshore Outsourcing and Productivity: Evidence from Japanese Firm-level Data Disaggregated by Tasks', Review of International Economics, 19(3), pp.555-567. 


\section{Keiko Ito}

Kambayashi, R. and K. Kiyota (2015), 'Disemployment Caused by Foreign Direct Investment? Multinationals and Japanese Employment', Review of World Economics, 151(3), pp.433-460.

Kawaguchi, D. and Y. Mori (2016), 'Why Has Wage Inequality Evolved So Differently Between Japan and the US? The Role of the Supply of CollegeEducated Workers', Economics of Education Review, 52(C), pp.29-50.

Keller, W. and H. Utar (2016), 'International Trade and Job Polarization: Evidence at the Worker-Level,' NBER Working Paper, No. 22315. Cambridge, MA: National Bureau of Economic Research.

Kimura, F. and K. Kiyota (2006), 'Exports, FDI, and Productivity: Dynamic Evidence from Japanese Firms', Review of World Economics, 142(4), pp.695-719.

Kiyota, K. and S. Maruyama (2017), 'ICT, Offshoring, and the Demand for PartTime Workers: The Case of Japanese Manufacturing', Journal of Asian Economics, 48(C), pp.75-86.

Mairesse, J. and P. Mohnen (2002), 'Accounting for Innovation and Measuring Innovativeness: An Illustrative Framework and an Application', The American Economic Review, 92(2), pp.226-230.

Mayer, T. and G.I.P. Ottaviano (2008), 'The Happy Few: The Internationalisation of European Firms', Intereconomics, 43(3), pp.135-148.

METI (2012), White Paper on International Economy and Trade 2012. Tokyo: Ministry of Economy, Trade and Industry.

Oldenski, L. (2012), 'Export Versus FDI and the Communication of Complex Information', Journal of International Economics, 87(2), pp.312-322.

RIETI (2015), Japan Industrial Productivity Database 2015 (JIP Database 2015): Investment and Capital Stock in Intangible Assets. Tokyo: Research Institute of Economy, Trade and Industry. https://www.rieti.go.jp/en/database/JIP2015/ index.html (accessed 7April2019).

Sakurai, K. (2014), 'Gurobaru-ka to Nihon no Rodoshijo: Boeki ga Chingin Kakusa ni ataeru Eikyo wo Chushin ni' (Globalization and the Japanese Labour Market: Focusing on the Impact of International Trade on Wage Gaps), Bank of Japan Working Paper, 14-J-5. Tokyo: Bank of Japan.

Sasaki, H. and K. Sakura (2004), 'Seizogyo ni okeru Jukuren Rodo he no Juyo Shifuto: Sukiru Henko-teki Gijutsu Shimpo to Gurobaru-ka no Eikyo' (The Demand Shift to Skilled Labor in the Manufacturing Sector: The Impact of SkillBiased Technological Change and Globalization, Bank of Japan Working Paper, 04-J-17. Tokyo: Bank of Japan.

Tanaka, A. (2012a), 'Firm Productivity and the Number of FDI Destinations: Evidence from a Non-Parametric Test', Economics Letters, 117(1), pp.1-3.

Tanaka, A. (2012b), 'The Effects of FDI on Domestic Employment and Workforce Composition', RIETI Discussion Paper, No. 12-E-069. Tokyo: Research Institute of Economy, Trade and Industry.

Tanaka, A (2018), 'Why Do Exporters and Multinational Firms Pay Higher Wages? Evidence from Japanese Linked Employer-Employee Data', Kyoto University Graduate School of Economics Discussion Paper Series, No. E-17-013. Kyoto: Kyoto University.

Taniguchi, M. (2019), 'The Effect of an Increase in Imports from China on Regional Labor Markets in Japan', Journal of the Japanese and International Economies, 51, pp.1-18. 
Todo, Y. (2011a), 'Quantitative Evaluation of the Determinants of Export and FDI: Firm-Level Evidence from Japan', The World Economy, 34(3), pp.355-381.

Todo, Y. (2011b), Nihon Keizai no Sokojikara: Garyo ga Mezameru-toki (The Underlying Strength of the Japanese Economy: The Time When the Unrecognized Genius Arises from Sleep). Tokyo: Chuokoron-Shinsha.

Todo, Y. and H. Sato (2014), 'Effects of Presidents' Characteristics on Internationalization of Small and Medium Firms in Japan', Journal of the Japanese and International Economies, 34, pp.236-255.

Tomiura, E. (2003), 'The Impact of Import Competition on Japanese Manufacturing Employment', Journal of the Japanese and International Economies, 17(2), pp.118-133.

Tomiura, E. (2007) 'Foreign Outsourcing, Exporting, and FDI: A Productivity Comparison at the Firm Level', Journal of International Economics, 72(1), pp.113-127.

Tomiura, E., R. Wakasugi, and L. Zhu (2014), 'Task Content of Trade: A Disaggregated Measurement of Japanese Changes', Japanese Economic Review, 65(2), pp.238-251.

Wagner, J. (2007), 'Exports and Productivity: A Survey of the Evidence from FirmLevel Data', The World Economy, 30(1), pp.60-82.

Wagner, J. (2011), 'Offshoring and Firm Performance: Self-Selection, Effects on Performance, or Both?', Review of World Economics, 147(2), pp.217-247.

Wagner, J. (2012), 'International Trade and Firm Performance: A Survey of Empirical Studies Since 2006', Review of World Economics, 148(2), pp.235-267.

Wakasugi, R., B. Ito, T. Matsuura, H. Sato, A. Tanaka, and Y. Todo (2011), 'Features of Japanese Internationalized Firms: Findings Based on Firm-Level Data', in R. Wakasugi (ed.) Internationalization of Japanese Firms: Evidence from Firm-level Data. Tokyo: Springer, pp.15-45.

Yamashita, N. (2008), 'The Impact of Production Fragmentation on Skill Upgrading: New Evidence from Japanese Manufacturing', Journal of the Japanese and International Economies, 22(4), pp.545-565.

Yamashita, N. and K. Fukao (2010), 'Expansion Abroad and Jobs at Home: Evidence from Japanese Multinational Enterprises', Japan and the World Economy, 22(2), pp.88-97.

Yamashita, N. and I. Yamauchi (2020), 'Innovation Responses of Japanese Firms to Chinese Import Competition', The World Economy, 43(1), pp. 60-80

Yashiro, N. and D. Hirano (2010), 'Anatomy of Learning-from-Exporting: Role of Foreign Knowledge Acquisition', RIETI Discussion Paper, No. 10-E-053. Tokyo: Research Institute of Economy, Trade and Industry. 


\section{Keiko Ito}

\section{Appendix}

Table 5A.1 Recent Empirical Studies on the Economic Impact of Globalisation Focusing on Japan

Author(s) and date

Findings

1. Globalization and firm productivity

Wakasugi et al. (2011) Exporters/MNEs have higher TFP than non-

Tanaka (2012a)

Kimura and

Kiyota (2006)

Todo (2011a)

Todo (2011b)

Hijzen, Inui, and

Todo (2010)

Ito, Tomiura, and

Wakasugi (2011)

2. Exporting and firm characteristics

Wakasugi et al. (2011) The largest 10\% of exporters account for $92 \%$ of Japan's total exports.

Ito $(2019)$

Inui, Ito, and

Miyakawa (2015)

Inui, Ito, and

Miyakawa (2017)

3. Innovation and internationalization

There is a huge productivity gap between the top exporters and other exporters.

Firms that have access to information on foreign markets via their main bank are more likely to start exporting.

Many export starters stop exporting in a short period. More R\&D-intensive firms tend to survive in export markets for a longer period.

Ito and

Lechevalier (2010)

Ito and Tanaka (2016)

Haneda and Ito (2014)

Firms engaged in R\&D activities are more likely to improve their productivity after entering export markets.

Exporters engaged in R\&D activities (either inhouse $\mathrm{R} \& \mathrm{D}$ or $\mathrm{R} \& \mathrm{D}$ outsourcing) are more productive than non-exporters and exporters with no R\&D.

New products tend to make up a much larger of sales for firms engaged in international activities than for domestic firms.

Branstetter (2006)

Japanese firms investing in the United States receive significant knowledge spillovers from US firms. In addition, US firms also receive knowledge spillovers from Japanese firms that have invested in the United States. 
Table 5A.1 (Continued)

Author(s) and date

Yashiro and

Hirano (2010)

Yamashita and

Yamauchi (2020)

Ito et al. (2019)
Findings

Exporters that gather various kinds of information from foreign markets are more likely to succeed in technology upgrading and development of new products.

Exporters/Importers tend to file for more patents in response to increased import competition from China.

Exporters in sectors with higher network centrality tend to file for more high-quality patents.

4. Globalization and domestic employment.

Tomiura (2003)

Sakurai (2014)

Import competition has a negative effect on domestic employment.

Factor-contents of trade estimation results suggest that the net impact of exports and imports on domestic employment is rather limited.

Taniguchi (2019)

Yamashita and Fukao (2010)

Kambayashi and Kiyota (2015)

Ando and Kimura (2017)

Ito and Tanaka (2014)

5. Impact on skill composition

Imports from China have a positive effect on manufacturing employment.

There is no significant negative relationship between overseas employment by Japanese MNEs and their domestic employment.

Manufacturing disemployment in Japan is not driven by the reallocation of labour from Japan to overseas via FDI.

Japanese MNEs that expand overseas operations tend to increase domestic employment.

There is no significant negative relationship between employment by domestic suppliers and overseas expansion of their customers.

Ito and Fukao (2005)

Increases in imports of intermediate inputs increase the share of skilled workers in the Japanese manufacturing sector.

Ahn Fukao, and Ito $(2008)$

Yamashita (2008)

Kiyota and Maruyama (2017)

Head and Ries (2002)

Hayakawa et al. (2013)

Tanaka (2012b)
There is a positive relationship between intermediate input imports from Asia and skill intensity in Japan.

There is a positive relationship between intermediate input imports from Asia and skill intensity in Japan.

Offshoring increases the demand for high-skill workers in Japan.

Expansion of overseas production of Japanese MNEs increases the skill intensity at home.

Expansion of overseas production of Japanese MNEs increases the skill intensity at home.

The share of temporary workers dispatched from staffing companies increases after a firm becomes a multinational. 


\section{Keiko Ito}

Table 5A.1 (Continued)

Author(s) and date Findings

6. Impact on wages, etc.

Sasaki and Sakura (2004) Import competition and offshoring increase the wage gap between skilled and unskilled workers.

Sakurai (2014)

Endoh (2018)

Import competition and offshoring increase the wage gap between skilled and unskilled workers.

Offshoring increases the wage gap between skilled and unskilled workers.

Burstein and

Vogel (2017)

International trade increases the wage gap between skilled and unskilled workers by $5.1 \%$ on average for 60 countries, but the impact cpcprintis is only approximately $2 \%$ in the case of Japan.

Tomiura, Wakasugi, and Zhu (2014)

Japan's net exports of routine tasks significantly decreased from 1995 to 2005.

7. Inter-industry impact of globalization

Ito and Ikeuchi (2017) Firms are more likely to shut down domestic establishments in more routine task-intensive industries after they became a multinational.

Fabinger, Shibuya, and Taniguchi (2017)

Imports from China have a negative effect on value added growth in upstream industries but a positive effect in downstream industries.

FDI $=$ foreign direct investment, $\mathrm{MNE}=$ multinational enterprise, $\mathrm{R} \& \mathrm{D}=$ research and development, TFP = total factor productivity. Source: Author's compilation. $\mathrm{MNE}=$ Multinational Enterprises. R\&D = Research \& Development. TFP = Total Factor Productivity. FDI = Foreign Direct Investment. Source: Author's compilation. 